\title{
Mushroom Production for Self Employment - An Impact Study
}

\author{
R. Nagaraj, P. Arunkumar*, B.C. Hanumanthaswamy and Jyoti M. Rathod \\ ICAR-Krishi Vigyan Kendra, UAHS, Shivamogga-577204 Karnataka, India \\ *Corresponding author
}

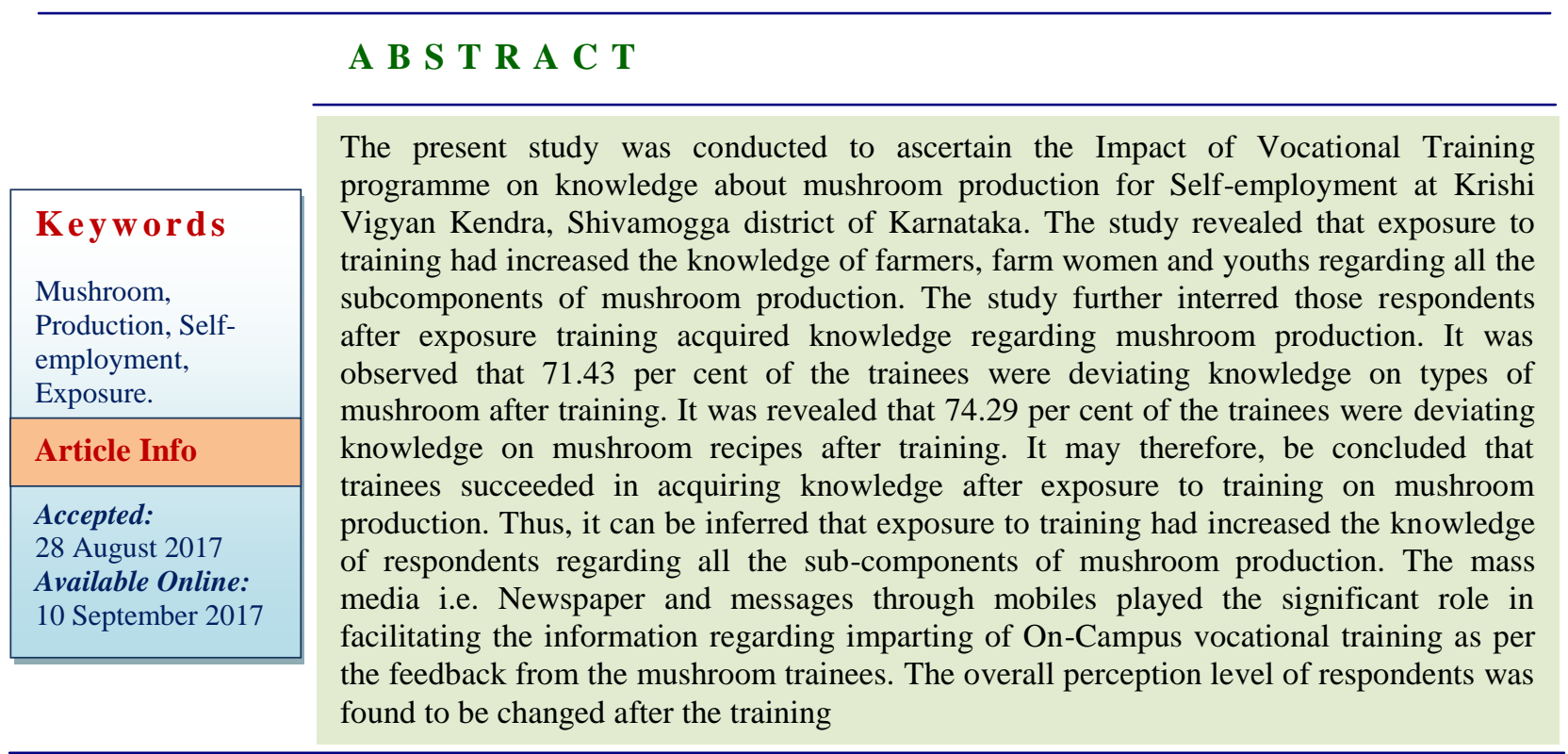

\section{Introduction}

India is primarily an agriculture- based country. The diversity in soil and climatic conditions allows a production of variety of crops in different parts of the country. This provides vast potential for the cultivation of mushrooms due to ample availability of raw materials and conducive climatic conditions. In a country, like India where vegetarians dominate, every attempt should be made to popularise a vegetable protein source like mushroom (Nita bahal, 1998). FAO has recommended mushrooms as a food item contributing to protein nutrition of the developing countries. Hence, there is a demand for technology at grass root level to enable people to break away from the poverty trap and to acquire a sense of livelihood. Extension and training have a generally been considered the outlet for an exchange of concepts with in a community. Therefore, trainings have been widely accepted strategy with high returns on investment.

No leaves, no buds, no flowers yet fruits, this miracle played only by mushroom. This unique fruit is basically a gift of nature to poor as evident from its appearance on thatched house and rotten woods just after first shower. But its taste and flavour soon introduced its delicious dish in the kitchen of 
aristocrats and elites of the society. Mushroom have prized as the food of God on an account of their nutritive value, special flavour and medicinal property. Mushroom is an indoor crop, grown independent of sunlight and do not require fertile land (Chadda and Sharma, 1995).

In addition to their role in agricultural production of farmers, farm women's and youths are gainfully employed in agri-based allied activities like mushroom production, animal husbandry, dairying, poultry, sheep rearing, horticulture, rabbit rearing, beekeeping, floriculture, fruit preservation, post-harvest technology, value added food products etc. Mushroom production is a friendly profession.

Mushroom production is simple, low cost, and suitable for rural areas, is labour intensive and can provide employment in both the rural areas and semi-urban.

Mushroom production will improve their socio-economic condition of farmers, families and solve employment problems of both literate and illiterate, especially in rural areas.

Keeping in view the increasing demand of mushroom due to globalization and opening of the economy, the present study was undertaken with the specific objective:

To assess the impact of training on knowledge about mushroom production as an enterprise/self-employment.

\section{Materials and Methods}

The vocational training program on mushroom production was focused on poor farmers, farm women's and youths for those who have interested in self-employment. The study was conducted at ICAR-KVK, Shivamogga Karnataka. A total of 35 respondents were selected randomly for training, out of 35 respondents 22 were men and 13 were women. Thorough training on various aspects of mushroom production was given which included the cultivation techniques, preparation of spawn, substrates preparation, marketing of fresh product, exposure visit, preservation, demonstration units, cost benefit ratio, etc.

The impact of the training was assessed by parameters such as impact of knowledge and change perception level of mushroom growers.

Appropriate schedule was prepared which was pre evaluation and post evaluation for its validity before and after data collection. Statistical tools were used that is frequency and percentage.

Methodology of table 2:

Deviation/change of

$$
\text { After training - Before training }
$$

Knowledge $=$ - - Total respondents

\section{Details of the technology}

\section{Raw material used}

Paddy straw, jowar seeds, polythene bags, cooking utensils, spawns, and polythene sheets were the materials used for mushroom spawn and cultivation.

\section{Results and Discussion}

\section{Profile of the mushroom production respondents}

Age

Majority of the respondents 68.57 per cent were middle aged, followed by 17.14 per cent and 14.28 per cent of old and young aged, respectively. 


\section{Education}

Majority of the respondents 34.28 per cent were received college. Whereas, 28.57 per cent of the respondents have studied up to graduation and 25.75 per cent have studied up to high school.

\section{Family size}

Table 1 indicates that, 45.71 per cent of the respondents had small family size, 28.57 per cent of them had big size family and remaining 25.71 per cent had medium size in their families.

\section{Annual income}

Table 1 showed that, 68.57 per cent of the respondents were getting low annual income, 20.00 per cent of them had medium annual income and remaining 11.42 per cent were getting high annual income.

\section{Mushroom production experience}

Majority of the respondents 88.57 per cent of the respondents had low experience, 8.57 per cent of them had medium experience and remaining 2.85 per cent had high mushroom production experience.

\section{Mass media participation}

Table 1 indicated that, 40.00 per cent of the respondents had low mass media participation.

Whereas, 31.42 per cent of them had medium mass media participation and remaining 28.57 per cent had high mass media participation.

\section{Extension participation}

Majority of the respondents 48.57 per cent of the respondents had medium extension participation, 28.57 per cent of them had low extension participation and remaining 22.85 per cent had high extension participation.

\section{Social participation}

Table 1 revealed that, 51.42 per cent of the respondents had medium social participation. Whereas, 28.57 per cent of them had high social participation and remaining 20.00 per cent had low social participation.

Change in knowledge of respondents for mushroom production pre exposure training, post-exposure training and ' $t$ ' test were computed for all the sub-components of mushroom production which were presented in Table 2. The overall knowledge level of respondents was found to be changed after the training. Change in knowledge regarding mushroom production was recorded for subcomponents. It was observed that nutritional importance of mushroom, types of mushroom, raw material, mushroom Spawn, importance of Casing, required temperature and humidity for fruiting, harvesting methodology, preservation techniques, marketing channels, awareness and availability of loans and subsidies from the government and mushroom recipes. It may therefore, be concluded that trainees succeeded in acquiring knowledge after exposure to training on mushroom production. Thus, it can be inferred that exposure to training had increased the knowledge of respondents regarding all the sub-components of mushroom production. In table 2 it was observed that 62.85 per cent of the respondents were deviating in knowledge on nutritional importance of mushroom after training. Whereas, 71.43 per cent of the trainees were deviating knowledge on types of mushroom after training. While, 57.14 per cent of the respondents were deviating in knowledge on raw material used for mushroom production after training. It was revealed that 74.29 per cent of the trainees 
were deviating knowledge on mushroom recipes after training. Whereas, 74.29 per cent of the trainees were deviating knowledge on harvesting methodology after training.
Whereas, 62.86 per cent of the trainees were deviating knowledge on awareness and availability of loans and subsidies from the government.

Table.1 Distribution of respondents according to their socio economic profile $\mathrm{N}=35$

\begin{tabular}{|c|c|c|c|}
\hline \multirow{2}{*}{\begin{tabular}{|l|} 
Sl. No. \\
1.
\end{tabular}} & \multirow{2}{*}{ characteristics } & \multicolumn{2}{|c|}{ Mushroom production trainees } \\
\hline & & Frequency & Percentage \\
\hline & \multicolumn{3}{|l|}{ Age } \\
\hline & Young (less than 30years) & 5 & 14.28 \\
\hline & Medium (31 to 50 years) & 24 & 68.57 \\
\hline & Old (more than 50 years) & 6 & 17.15 \\
\hline \multirow[t]{7}{*}{2.} & \multicolumn{3}{|l|}{ Education } \\
\hline & Illiterate & 0 & 0.0 \\
\hline & Primary school & 2 & 5.71 \\
\hline & Middle school & 2 & 5.72 \\
\hline & High school & 9 & 25.71 \\
\hline & College & 12 & 34.28 \\
\hline & Graduation and above & 10 & 28.57 \\
\hline \multirow[t]{4}{*}{3.} & \multicolumn{3}{|l|}{ Family size } \\
\hline & Small (up to 4 members) & 16 & 45.71 \\
\hline & Medium (5 to 8 members) & 9 & 25.72 \\
\hline & Big (above 8 members) & 10 & 28.57 \\
\hline \multirow[t]{4}{*}{4.} & \multicolumn{3}{|l|}{ Annual income } \\
\hline & Low & 24 & 68.57 \\
\hline & Medium & 7 & 20.00 \\
\hline & High & 4 & 11.42 \\
\hline \multirow[t]{4}{*}{5.} & \multicolumn{3}{|c|}{ Mushroom production experience } \\
\hline & Low & 31 & 88.57 \\
\hline & Medium & 3 & 8.57 \\
\hline & High & 1 & 2.86 \\
\hline \multirow[t]{4}{*}{6.} & \multicolumn{3}{|l|}{ Mass media participation } \\
\hline & Low & 14 & 40.00 \\
\hline & Medium & 11 & 31.43 \\
\hline & High & 10 & 28.57 \\
\hline \multirow[t]{4}{*}{7.} & \multicolumn{3}{|l|}{ Extension participation } \\
\hline & Low & 10 & 28.57 \\
\hline & Medium & 17 & 48.57 \\
\hline & High & 8 & 22.86 \\
\hline \multirow[t]{4}{*}{8.} & \multicolumn{3}{|l|}{ Social participation } \\
\hline & Low & 7 & 20.00 \\
\hline & Medium & 18 & 51.43 \\
\hline & High & 10 & 28.57 \\
\hline
\end{tabular}


Table.2 Deviation in knowledge of respondents about mushroom production $\mathrm{N}=35$

\begin{tabular}{|l|l|l|l|l|}
\hline Sl. No. & Components & $\begin{array}{l}\text { Pre training } \\
(\%)\end{array}$ & $\begin{array}{l}\text { Post training } \\
(\%)\end{array}$ & $\begin{array}{l}\text { Deviation in } \\
\text { knowledge }\end{array}$ \\
\hline 1. & $\begin{array}{l}\text { Nutritional importance } \\
\text { of mushroom }\end{array}$ & $9(25.71)$ & $31(88.57)$ & $+22(62.85)$ \\
\hline 2. & Types of mushroom & $5(14.28)$ & $30(85.71)$ & $+25(71.43)$ \\
\hline 3. & Raw materials & $8(22.85)$ & $28(80.00)$ & $+20(57.14)$ \\
\hline 4. & Mushroom Spawn & $2(5.71)$ & $27(77.14)$ & $+25(71.43)$ \\
\hline 5. & Importance of Casing & $1(2.85)$ & $21(60.00)$ & $+20(57.14)$ \\
\hline 6. & $\begin{array}{l}\text { Optimum temperature } \\
\text { and humidity for } \\
\text { fruiting }\end{array}$ & $3(8.57)$ & $25(71.42)$ & $+22(62.86)$ \\
\hline 7. & Harvesting methodology & $2(5.71)$ & $28(80.00)$ & $+26(74.29)$ \\
\hline 8. & Preservation techniques & $3(8.57)$ & $21(60.00)$ & $+18(51.43)$ \\
\hline 9. & Marketing channels & $0(0.0)$ & $19(54.28)$ & $+19(54.28)$ \\
\hline 10. & $\begin{array}{l}\text { Awareness and } \\
\text { availability of loans and } \\
\text { subsidies from the } \\
\text { government }\end{array}$ & $2(5.71)$ & $24(68.57)$ & $+22(62.86)$ \\
\hline 11. & Mushroom recipes & $5(14.28)$ & $31(88.57)$ & $+26(74.29)$ \\
\hline
\end{tabular}

Table.3 Changes in perception level of respondents for mushroom production $(\mathrm{N}=35)$

\begin{tabular}{|l|l|c|c|}
\hline $\begin{array}{l}\text { Sl. } \\
\text { No. }\end{array}$ & Explanatory variables & Before training $(\%)$ & After training (\%) \\
\hline 1. & Mushroom as vegetarian food & 8.57 & 100.00 \\
\hline 2. & Aware of the nutrient food value & 11.42 & 88.57 \\
\hline 3. & $\begin{array}{l}\text { Basic knowledge of mushroom } \\
\text { cultivation and production }\end{array}$ & 14.28 & 85.71 \\
\hline 4. & $\begin{array}{l}\text { Materials used for different types of } \\
\text { mushroom production }\end{array}$ & 14.28 & 80.00 \\
\hline 4. & $\begin{array}{l}\text { Profitability in mushroom } \\
\text { cultivation }\end{array}$ & 25.71 & 97.14 \\
\hline 5. & Identification of edible mushroom & 17.14 & 68.57 \\
\hline 6. & Material used for spawn production & 20.00 & 88.57 \\
\hline 7. & $\begin{array}{l}\text { Cost benefit ratio of mushroom } \\
\text { production }\end{array}$ & 22.85 & 60.00 \\
\hline 8. & Local marketing linkages & 5.71 & 74.28 \\
\hline 9. & $\begin{array}{l}\text { Awareness of loans, schemes and } \\
\text { subsides for establishment of } \\
\text { mushroom production unit }\end{array}$ & 2.85 & \\
\hline
\end{tabular}


ICAR-KVK intervention in Mushroom promotion and production enterprise

\begin{tabular}{|l|l|l|}
\hline Capacity building & Target people & Type of intervention \\
\hline Three day & Farmers, Farm women and & Training \\
& Youths & Exposure \\
& & Farm visits \\
& & Spawn production \\
& & Demonstration on oyster \\
& mushroom \\
& & Mushroom experience sharing \\
& & among farmers \\
& & Short Message Service \\
& & Popularizing through mass \\
& & media \\
& & Visit to mushroom bio centre \\
\hline
\end{tabular}

Mushroom (Pleurotus spp.) commonly called as oyster mushroom has been standardized on locally available substrates. The flow chart of the technology is as follows

The cultivation technology of pink, gray, white, yellow, brown and black oyster mushrooms is same with minor differences in duration of spawn running and cropping

$$
\downarrow
$$

Substrate preparation (All kinds of straw and other agro-wastes) Chopped in small $(1-2 \mathrm{~cm}$

$$
\text { pieces) }
$$

Soaked in water for 2-3 hours

Substrate can be pasteurized by hot water $\left(80^{\circ} \mathrm{C}\right)$ for 2 hours (no prior soaking required in this case), suitable for small scale production OR steam pasteurization at $80^{\circ} \mathrm{C}$ for 2 hours (in autoclave or special steam chambers), suitable for semi-commercial production

Fill one Kg pasteurized substrate (65\% moisture) in Polypropylene bags, plug with nonabsorbent cotton. (Aseptically, @ 5\% of wet substrate) while filling in bags in pasteurization method OR top spawning in sterilized method

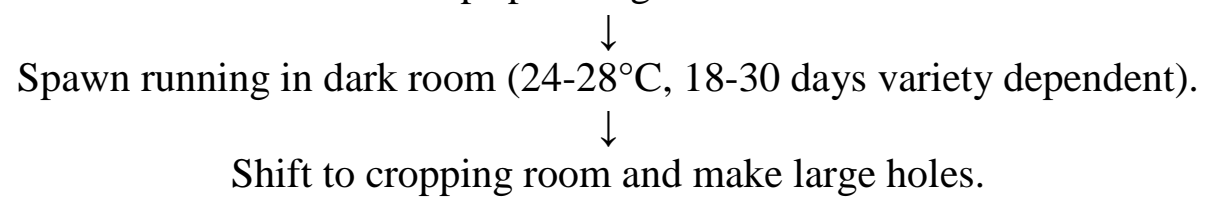

Pinhead initiation (2-7 days after opening, $13-30^{\circ} \mathrm{C}$, variety dependent, humidity $80-85 \%$, light, ventilation).

$\downarrow$

Harvesting (2-4 days after pinhead initiation, variety dependent) 


\section{Changes in perception level}

The trainee respondents were inspired greatly by the easy method of production. The mushrooms were included in their daily diet and supplemented additional nutrition to them. The perception level of the respondents about mushroom and its production before and after the training is presented in Table 3. The overall perception level of respondents was found to be changed after the training. The perception level on mushroom cultivation technology, their food and nutritional values, economics in cultivation, etc were considered profitability. The mind set was changed and about cent per cent respondents felt that mushroom as vegetarian food. While, 97.14 per cent respondents were considered profitability in mushroom cultivation. Whereas, 74.28 per cent respondents were enhanced awareness of loans, schemes and subsides for establishment of mushroom production unit and 88.57 per cent of the trainees were improved the perception level of Cost benefit ratio of mushroom production. 85.71per cent were enhanced the basic knowledge of mushroom cultivation and production.

Awareness and training on mushroom production helped in income generation, nutrient supplement and in profitable marketing of farmers, farm women and youths. Farmers realized the importance of mushroom and incorporated it in their diet. It also provided an opportunity to strengthen the link between farmers and scientists which helped in technology dissemination and overall development of weaker section.

\section{References}

Bahl, N., 1998. Hand Book of Mushrooms. New Delhi. Oxford and IBH publishing Co.

Chadha, K.L., and Sharma, S.R. 1995. Mushroom research in India History, infrastructure and achievements. INS: Advances in Horticulture, (Eds. Chadha, K.L. and Sharma, S.R). Malhotra Publishing House, New Delhi. 13: 1-29.

\section{How to cite this article:}

Nagaraj, R., P. Arunkumar, B.C. Hanumanthaswamy and Jyoti M. Rathod. 2017. Mushroom Production for Self Employment - An Impact Study. Int.J.Curr.Microbiol.App.Sci. 6(9): 29912997. doi: https://doi.org/10.20546/ijcmas.2017.609.367 